\title{
Reflections on the development of international nuclear law
}

\author{
by Vanda Lamm*
}

\section{Introduction}

Over the course of more than seven decades, treaty norms on the production and utilisation of nuclear energy have been developed, which together form a special section within international law. These norms are the consequence of the unique nature of the field, namely that on the one hand some aspects of the uses of nuclear energy should be covered by totally new and special norms (e.g. in the field of disarmament, seeking to eliminate or at least to control the spread of nuclear weapons, and nuclear weapons tests) and on the other that several traditional legal solutions were not suitable for the problems that emerged in connection with other uses of nuclear energy (like liability).

In the following article, three aspects of the development of that special section of international law will be explored, namely: the close connections between the regulation of peaceful and military uses of nuclear energy; the effects of nuclear catastrophes on the development of international nuclear legislation and the interaction between soft law norms and binding norms in the area of nuclear law.

\section{Two-tier approach in nuclear energy regulation}

Since atomic bombs were dropped on Hiroshima and Nagasaki at the end of World War II (on 6 and 9 August 1945), ${ }^{1}$ nuclear disarmament has been a primary concern for humankind. Several nuclear disarmament treaties have been signed in the 70 or so years that have elapsed since then, ${ }^{2}$ yet the complete elimination of nuclear weapons remains a distant goal. This was acknowledged by the International Court of Justice in its Advisory Opinion on the "Legality of the threat or use of nuclear weapons", when it stated that "There is in neither customary nor conventional international law any comprehensive and universal prohibition of the threat or use of nuclear

\footnotetext{
* Emerita Professor of International Law (Social Research Centre, Hungarian Academy of Sciences; Széchenyi István University, Győr, Hungary).

${ }^{1}$ The bombings caused the death of over 130000 people in the space of a few seconds, and many others were killed by radiation.

${ }^{2}$ The most important are the:
}

- $\quad$ Treaty Banning Nuclear Weapon Test in the Atmosphere, in Outer Space and Under Water (1963), 480 UNTS 43, entered into force 10 October 1963 ;

- $\quad$ Treaty on the Non-Proliferation of Nuclear Weapons (1968), IAEA Doc. INFCIRC/140, 729 UNTS 169, entered into force 5 March 1970 (NPT);

- Comprehensive Nuclear-Test-Ban Treaty (1996) (not yet entered into force), available at: www.ctbto.org/fileadmin/content/treaty/treaty_text.pdf (Nuclear Test Ban Treaty);

- Interim Agreement between the United States of America and the Union of Soviet Socialist Republics on Certain Measures with respect to the Limitation of Strategic Offensive Arms (1972), entered into force 3 October 1972 (SALT I);

- Treaty between the United States of America and the Union of Soviet Socialist Republics on the Limitation of Strategic Offensive Arms, Together with Agreed Statements and Common Understandings regarding the Treaty (1979), did not enter into force (SALT II);

- $\quad$ Treaty between the United States of America and the Union of Socialist Soviet Republics on Further Reduction and Limitation of Strategic Offensive Arms (1991), entered into force 5 December 1994 (START I);

- Treaty between the United States of America and the Russian Federation on Further Reduction and Limitation of Strategic Offensive Arms (1993) (not yet entered into force) (START II); and

- nuclear weapons free zone treaties. 
weapons as such". ${ }^{3}$ With respect to the use of nuclear weapons in an armed conflict, the Court ruled "[b]y seven votes to seven, by the President's casting vote," that "However, in view of the current state of international law, and of the elements of fact at its disposal, the Court cannot conclude definitively whether the threat or use of nuclear weapons would be lawful or unlawful in an extreme circumstance of self-defence, in which the very survival of a State would be at stake". 4

Nuclear weapons cast a shadow over opportunities for the peaceful use of nuclear energy, and their regulations are very often grouped together. This two-tier approach is a feature of national and international legislation on the peaceful use of nuclear energy and of the activities of international organisations that oversee this area. In this respect, Pierre Strohl, referring to domestic law provisions and to international law on the use of nuclear energy states that nuclear law essentially has the purpose of addressing a specific hazard and takes its originality from that purpose. ${ }^{5}$ The close links between regulations on the peaceful use of nuclear energy and the prevention of its destructive use arise out of its dual nature, since in technical terms, peaceful uses of nuclear energy can be diverted for military purposes.

The Atomic Energy Commission is an example of the close links referred to above. This body was established after the Second World War by the United Nations (UN) General Assembly in 1946 with a mandate to present specific proposals on the control of atomic energy to ensure its application exclusively for peaceful purposes, and on the exclusion of any national use of an atomic weapon or any other weapon of mass destruction. ${ }^{6}$ This two-tier approach is also characteristic of the activities of other international nuclear organisations.

The International Atomic Energy Agency (IAEA), established in 1957 to encourage and facilitate the development and use of nuclear energy for peaceful purposes throughout the world as well as research into this field, is also responsible for introducing and applying safeguards to ensure "that assistance provided by it or at its request or under its supervision or control is not used in such a way as to further any military purpose". 7 The application of the IAEA safeguards was broadened considerably by Article III of the NPT, which provides for the Agency's safeguards to be applied in non-nuclear-weapon states parties. ${ }^{8}$ The Agency thus ensures that material, facilities and technology in such states are used for peaceful purposes and are not diverted for military use. Through the NPT, the Agency has become the leading verification body for the commitments arising out of one of the most important disarmament treaties of modern times. In the event of a state's failure to respect the safeguards, the IAEA, or more precisely its Board of Governors, can and must refer the matter to the Security Council, the primary UN body with particular

\footnotetext{
3 "Legality of the threat or use of nuclear weapons", Advisory Opinion of 8 July 1996, ICJ Reports 1996, para. 2(B), p. 266.

${ }^{4}$ Ibid., at para. 105(2)(E). For more information on the Advisory Opinion, see Boisson de Chazournes, B. and P. Sands (eds.) (1999), International Law, the International Court of Justice and Nuclear Weapons, Cambridge University Press, Cambridge, UK.

${ }^{5}$ Strohl, P. (1993), The Hazards Arising Out of the Peaceful Use of Nuclear Energy, Academy of International Law, The Hague, Centre for Studies and Research in International Law and International Relations, Martinus Nijhoff Publishers, Dordrecht, Netherlands, p. 23.

${ }^{6}$ See on this subject in particular Aron, A. (1946), "Le contrôle international de l'énergie atomique" [International control of atomic energy], Politique étrangère [Foreign politic], 1946, Vol. 11, No. 5, pp. 465-488.

${ }^{7}$ See Statute of the International Atomic Energy Agency (1956), 276 UNTS 3, entered into force 29 July 1957, Article XII.

${ }^{8}$ States with nuclear weapons can accept the application of the Agency's safeguards on a voluntary basis. On the safeguards system, see Rockwood, L. (2010), “The IAEA Safeguards System”, in NEA (ed.) (2010), International Nuclear Law: History, Evolution and Outlook, OECD, Paris, pp. 243-269. Over the years, the scope of the Agency's safeguards system has been broadened on the basis of safeguard agreements entered into under the nuclear-weapon-free zone treaties (see the Treaties of Tlatelolco, Rarotonga, Pelindaba and Bangkok).
} 
responsibility for maintaining international peace and security, and to the UN General Assembly for decisions to be taken on sanctions against a state that does not respect its obligations under the NPT. ${ }^{9}$

Security control systems are also found under the auspices of other international nuclear organisations. The predecessor of the Organisation for Economic Co-operation and Development's (OECD) Nuclear Energy Agency (NEA), the European Nuclear Energy Agency (ENEA), established in 1957 to further the development of the production and uses of nuclear energy for peaceful purposes, initially operated a security control mechanism that sought to "ensure that the operation of joint undertakings established by two or more Governments ... on the initiative or with the assistance of the Agency and [that] materials, equipment and services made available by the Agency or under its supervision ... shall not further any military purpose". ${ }^{10}$ Subsequently, with the creation of similar systems by other international nuclear organisations (IAEA and Euratom), the application of the ENEA's security control system was suspended. ${ }^{11}$ Euratom, the main objective of which is to favour the development of nuclear energy, has had a safeguards system since 1957, and according to Article 77 of the Euratom Treaty, ${ }^{12}$ Euratom safeguards must ensure that nuclear materials are not diverted to the possible production of nuclear weapons. In 1973, Euratom non-nuclear-weapon member states and the European Commission (EC) entered into an agreement with the IAEA on the application of safeguards under the NPT, and according to that agreement, Euratom, as a regional body, contributes to the implementation of the IAEA safeguarding system. ${ }^{13}$

The two-tier approach referred to above is also found in the NPT. It is well known that the latter distinguishes nuclear-weapon states from non-nuclear-weapon states. ${ }^{14}$ In this Treaty, nuclearweapon states undertake not to transfer nuclear weapons or to assist any non-nuclear-weapon state to acquire nuclear weapons or other nuclear explosive devices, or control over such weapons or explosive devices, while non-nuclear weapon states undertake not to receive the transfer of and not to manufacture nuclear weapons and thus decline to acquire them. ${ }^{15}$

The NPT, however, also contains a clause (Article IV) on the use of nuclear energy that recognises the inalienable right of all the parties to the Treaty to develop research, production and uses of nuclear energy for peaceful purposes. This clause highlights the commitment of states to

\footnotetext{
${ }^{9}$ Between 2006 and the adoption in 2015 of the Joint Comprehensive Plan of Action (2015), effective 18 October 2015, between the Islamic Republic of Iran and the E3/EU+3 group (China, the European Union, France, Germany, the Russian Federation, the United Kingdom and the United States), the UN Security Council adopted a series of sanctions against Iran on seven occasions, though they were lifted because Iran fulfilled its commitments under the Action Plan. Sanctions were also imposed on the Democratic People's Republic of Korea because of the nuclear tests carried out by the Pyongyang Government.

${ }^{10}$ Convention on the Establishment of a Security Control in the Field of Nuclear Energy (1957), entered into force 22 July 1959, Article $1(\mathrm{a})$.

${ }^{11}$ See Schwartz, J. (2010), “The OECD Nuclear Energy Agency”, in NEA (ed.) (2010), International Nuclear Law: History, Evolution and Outlook, OECD, Paris, pp. 32-33.

12 Treaty Establishing the European Atomic Energy Community (1957), 298 UNTS 167, entered into force 1 January 1958 (Euratom Treaty) (consolidated version Official Journal of the European Union (OJ) C 203 (7 June 2016)).

${ }^{13}$ See Kobia, R. (2008), “The EU and Non-Proliferation: Need for a Quantum Leap?”, Nuclear Law Bulletin, No. 81, OECD, Paris, pp. 42-43, and Schleicher, H.W. (1980), "Nuclear safeguards in the European Community: A Regional Approach", IAEA Bulletin, Vol. 22, No. 3, pp. 45-50.

${ }^{14}$ Nuclear-weapon states are those that detonated a nuclear weapon or another nuclear explosive device prior to 1 January 1967, notably China, the United States, France, the United Kingdom and the Soviet Union (now Russia).

${ }^{15}$ See NPT, Articles I and II.
} 
facilitate the fullest possible exchange of equipment, materials and scientific and technological information for the peaceful uses of nuclear energy. ${ }^{16}$

The close links between the peaceful use of nuclear energy and nuclear weapons nonproliferation in regulations concerning nuclear exports are evident. Since 1974, the Nuclear Suppliers Group (NSG), ${ }^{17}$ an international collection of countries supplying nuclear material, equipment and technologies, has drawn up guidelines on nuclear trade for peaceful purposes to ensure that such trade does not contribute to the proliferation of nuclear weapons. ${ }^{18}$

Links between disarmament and the peaceful use of nuclear energy are evident in the treaties establishing nuclear-weapon-free zones. ${ }^{19}$ The Treaty for the Prohibition of Nuclear Weapons in Latin America and the Caribbean ${ }^{20}$ thus provides not only for a prohibition on the testing, use, manufacture, production or acquisition of any nuclear weapons or participation in such activities, and on the storage, deployment or possession of nuclear weapons, but also states that nuclear material and facilities should be used exclusively for peaceful purposes. Similarly, the Agency for the Prohibition of Nuclear Weapons in Latin America and the Caribbean (Organismo para la Proscription de las Armas Nucleares en la America Latina) (OPANAL), created to ensure respect for the provisions of the Treaty of Tlatelolco, "has never forgotten that its major future task is to promote access to nuclear technology for exclusively peaceful purposes". ${ }^{21}$ It should be added that the other treaties establishing nuclear-weapon-free zones also refer to the peaceful use of nuclear energy.

\section{The influence of experience of nuclear accidents on international nuclear legislation}

The nuclear accidents that have occurred in recent times have highlighted not only the technical shortcomings but also the gaps and incoherence in legal regulations on the peaceful use of nuclear energy and have shown how important it is to have clear and effective rules at both national and international level.

\footnotetext{
${ }^{16}$ See Grae, S. (1995), “The Nuclear Non-Proliferation Treaty’s Obligation to Transfer Peaceful Nuclear Energy Technology: One Proposal of a Technology”, Fordham International Law Journal, Vol. 19, Issue 5, pp. 1985-1998; Lamm, V. (2007), "The Content and Extent of the Inalienable Right of States to develop Research, Production and Uses of Nuclear Energy for Peaceful Purposes (Article IV NPT)" in Pelzer, N. (2007), Bausteine eines globalen Atomrechtsregimes / Elements of a Global Nuclear Law Regime: Tagungsbericht der AIDN/INLA-Regionaltagung in Goslar 2006 [Proceedings of the AIDN / INLA Regional Conference in Goslar 2006], Nomos, Baden-Baden, pp. 55-67; Fleck, D. (2016), "The Right to Develop Research, Production and Use of Nuclear Energy for Peaceful Purposes: Shortcomings and Loopholes in Legal Regulation", in Black-Branch, J.L. and D. Fleck (eds.) (2016), Nuclear NonProliferation in International Law-Volume III: Legal Aspects of the Use of Nuclear Energy for Peaceful Purposes, Asser Press, The Hague, pp. 525-551.

${ }^{17}$ On the role and activities of the NSG, see IAEA (2015), “The Nuclear Suppliers Group: Its Origins, Role and Activities”, IAEA Doc. INFCIRC/539/Revision 6.

${ }^{18}$ See IAEA (2016), “Guidelines for Transfers of Nuclear-Related Dual-Use Equipment, Materials, Software, and Related Technology”, IAEA Doc. INFCIRC/254/Rev.10/Part2. The NSG Guidelines are implemented by each participating government in accordance with their national laws and practices. Decisions concerning exports are taken at national level, in accordance with national export control rules.

${ }^{19}$ On denuclearised zones, see Tabassi, L. (2009), "National Implementation and Enforcement of Nuclear-Weapon-Free Zone Treaties", Nuclear Law Bulletin, No. 83, OECD, Paris, pp. 29-57.

${ }^{20}$ Treaty for the Prohibition of Nuclear Weapons in Latin America (1967), 634 UNTS 326, entered into force 22 April 1968 (Treaty of Tlatelolco).

${ }^{21}$ See Román-Morey, E. (1995), "Latin America’s Treaty of Tlatelolco: Instrument for peace and development”, IAEA Bulletin, Vol. 37, No. 1, p. 35.
} 
The first major accident in a nuclear power plant occurred on 28 March 1979 at the Three Mile Island facility near Harrisburg, Pennsylvania in the United States. ${ }^{22}$ Despite the extremely serious nature of the accident, which released a rather small amount of radioactive material into the environment, there were no victims among personnel or the population. ${ }^{23}$ The event, however, led to changes in and helped to strengthen safety rules.

The most serious nuclear accident, at Chernobyl in the former Union of Soviet Socialist Republics (USSR) on 26 April 1986, was classified at the highest level, 7, on the INES scale. This catastrophe "was in fact a wake-up call for the "international nuclear community",24 and clearly demonstrated the gravity of a major accident and its consequences for human health and the natural environment. It also led to the realisation that a nuclear accident could cause huge damage not only in the installation state but also thousands of kilometres away. From a legal point of view, the Chernobyl tragedy helped to: (i) strengthen and broaden international co-operation in the case of a nuclear accidents; (ii) ensure the adoption of international conventions in areas that had previously been regulated by soft law standards; and (iii) bring international conventions on civil liability for nuclear damage up to date. ${ }^{25}$

The first lesson of the catastrophe was that inter-state co-operation had to be increased and facilitated in cases of nuclear accidents where one of the states was affected by an urgent situation with radioactive consequences. Two conventions were accordingly drafted some months after the accident within the framework of the IAEA: the Convention on Early Notification of a Nuclear Accident ${ }^{26}$ and the Convention on Assistance in the Case of a Nuclear Accident. ${ }^{27}$ These two treaties were drawn up and entered into force very quickly and became effective just a few months after the Chernobyl accident. ${ }^{28}$

The Early Notification Convention, which entered into force just one month after its adoption, seeks to strengthen international co-operation. The states parties to this Convention undertake to notify, directly or through the IAEA, states that are or may be physically affected, and provide them with information as soon as possible on any event occurring on their territory that has resulted or may result in an international transboundary release that could be of radiological

\footnotetext{
${ }^{22}$ The accident was classified at level 5 on the INES Scale (International Nuclear and Radiological Event Scale).

${ }^{23}$ See Perrow, C. (1981), “Normal Accident at Three Mile Island”, Society, July/August, Vol. 18, No. 5, pp. 17-26.

${ }^{24}$ Rautenbach, J., W. Tonhauser and A. Wetherall (2006), "Overview of the International Legal Framework Governing the Safe and Peaceful Uses of Nuclear Energy - Some Practical Steps" in NEA and IAEA (eds.), International Nuclear Law in the Post-Chernobyl Period, OECD, Paris, p. 7.

${ }^{25}$ See on this subject Kiss, A. (1986), "L'accident de Tchernobyl et ses conséquences au point de vue du droit international" [The Chernobyl accident and its consequences from the point of view of international law], Annuaire français de droit international [French Yearbook of International Law ], Vol. 32, No. 1, pp. 139-152; Pelzer, N. (1987), "The impact of the Chernobyl accident on international nuclear energy law", Archiv des Völkerrechts [Archives of International Law], Vol. 25, No. 3, pp. 294-311; Pelzer, N. (2006), "Learning the Hard Way: Did the Lessons Taught by the Chernobyl Nuclear Accident Contribute to Improving Nuclear Law?" in NEA and IAEA (eds.), International Nuclear Law in the Post-Chernobyl Period, OECD, Paris, pp. 73-118; Schwartz, J. (2006), "International Nuclear Third-Party Liability Law: the Response to Chernobyl" in NEA and IAEA (eds.), International Nuclear Law in the Post-Chernobyl Period, OECD, Paris, pp. 41-80; Kuş, S. (2011), "International nuclear law in the 25 years between Chernobyl and Fukushima and beyond...", Nuclear Law Bulletin, No. 87, OECD, Paris, pp. 7-26.

${ }^{26}$ Convention on Early Notification of a Nuclear Accident (1986), IAEA Doc. INFCIRC/335, 1439 UNTS 276, entered into force 27 October 1986 (Early Notification Convention).

${ }^{27}$ Convention on Assistance in the Case of a Nuclear Accident or Radiological Emergency (1986), IAEA Doc. INFCIRC/336, 1457 UNTS 134, entered into force 26 February 1987 (Assistance Convention).

${ }^{28}$ On these Conventions, see Moser, B. (1989), "The IAEA Conventions on Early Notification of a Nuclear Accident and on Assistance in the Case of a Nuclear Accident or Radiological Emergency", Nuclear Law Bulletin, No. 44, OECD, Paris, pp. 10-23.
} 
safety significance for another state. Similarly, the Assistance Convention seeks to facilitate co-operation between states in the event of a radiological emergency to minimise its consequences and to protect life, property and the environment from the effects of radioactive releases.

A very important instrument for areas that were previously not regulated by the treaties was the Convention on Nuclear Safety, ${ }^{29}$ adopted in 1994 under IAEA auspices. The aim of the CNS is "to achieve and maintain a high level of nuclear safety" in land-based civil nuclear power plants, "to establish and maintain effective defences in nuclear installations against potential radiological hazards in order to protect individuals, society and the environment", and "to prevent accidents with radiological consequences and to mitigate such consequences should they occur". ${ }^{30}$ As noted in the Preamble, the CNS has its roots in the fundamental safety principles (at the time contained in The Safety of Nuclear Installations of $1993^{31}$, but now addressed in the 2006 Fundamental Safety Principles ${ }^{32}$ ). Under the Convention, each contracting party must submit reports on the implementation of their obligations under the Convention for peer review at periodic meetings. ${ }^{33}$

The Joint Convention on the Safety of Spent Fuel Management and on the Safety of Radioactive Waste Management ${ }^{34}$ was adopted in 1997 and complements the CNS. One of the characteristics of this Convention is that it brings two separate subjects together within a "joint" framework: the safety of spent fuel and the safety of radioactive waste management. The objective of the Joint Convention is "to achieve and maintain a high level of safety [] in spent fuel and radioactive waste management, ... so that individuals, society and the environment are protected from harmful effects of ionizing radiation". The obligations of the contracting parties fall into two main types. ${ }^{35}$ The first is based on provisions of the CNS and on IAEA Safety Standards Series, while the second requires the contracting parties to draw up regular reports on the implementation of these obligations, which are submitted to a question and answer session and then peer reviewed at meetings of the contracting parties, similar to that which is done for the CNS.

With regard to the importance of the two conventions referred to above, Selma Kuş correctly pointed out that Chernobyl "facilitated international co-operation in fields that were until then strictly protected by individual states as falling under their sovereign jurisdiction". ${ }^{36}$ It became

\footnotetext{
${ }^{29}$ Convention on Nuclear Safety (1994), IAEA Doc. INFCIRC/449, 1963 UNTS 293, entered into force 24 October 1996 (CNS).

${ }^{30}$ See on this subject Reyners, P. (1995), "La Convention de 1994 sur la sûreté nucléaire" [The 1994 Convention on Nuclear Safety], Revue Général de Droit International Public [General Review of Public Intenrational Law], No. 99, pp. 605-621; Jankowitsch-Prevor, O. (2006), "The Convention on Nuclear Safety" in NEA and IAEA (eds.), International Nuclear Law in the Post-Chernobyl Period, OECD, Paris, pp. 155-168. Strohl, P. (1994), "La Convention sur la sûreté nucléaire" [The Convention on Nuclear Safety], Annuaire français de droit international [French International Law Directory], Vol. 40, No. 1, pp. 804-822.

${ }^{31}$ IAEA (1993), The Safety of Nuclear Installations, Safety Series No. 110, IAEA, Vienna (no longer valid).

${ }^{32}$ IAEA (2006), Fundamental Safety Principles, SF-1, IAEA, Vienna.

${ }^{33}$ For mroe information, see IAEA (2017), Convention on Nuclear Safety (CNS): An Introduction to the CNS and Its Associated Rules of Procedure and Guidelines, IAEA, Vienna, available at: http://www-ns.iaea.org/downloads/ni/safety_convention/related-documents/cnsbrochure_final_2017-01-23.pdf.

${ }^{34}$ Joint Convention on the Safety of Spent Fuel Management and on the Safety of Radioactive Waste Management (1997), IAEA Doc. INFCIRC/546, 2153 UNTS 357, entered into force 18 June 2001 (Joint Convention).

${ }^{35}$ See Tonhauser, W. and O. Jankowitsch-Prevor (2006), "The Joint Convention on the Safety of Spent Fuel Management and on the Safety of Radioactive Waste Management", in NEA and IAEA (eds.), International Nuclear Law in the Post-Chernobyl Period, OECD, Paris, pp. 201-214; de Kageneck, A. and C. Pinel (1998), "The Joint Convention on the Safety of Spent Fuel Management and on the Safety of Radioactive Waste Management", International \& Comparative Law Quarterly, Vol. 47, No. 2, pp. 409-425.

${ }^{36}$ Kuş, S. (2011), supra note 25, p. 8.
} 
apparent after Chernobyl that the treaty on compensation for cross-border damage, the Vienna Convention on Civil Liability for Nuclear Damage, ${ }^{37}$ adopted in 1963 under IAEA auspices, could represent an appropriate instrument for settling compensation claims brought by foreign victims in similar situations. An urgent need then arose to adapt the Vienna Convention's provisions to take account of the technological progress made over the 25 years that had elapsed. After the Chernobyl accident, the then Soviet Union refused to pay compensation to the foreign victims. Some observers felt that if the Soviet Union had been bound by the Vienna Convention, foreign victims would at least have had a chance to receive damages. Their compensation, however, posed a problem: the amount finally payable under the 1963 Vienna Convention would have made it possible to satisfy only a ridiculously minimal proportion of the claims for compensation in light of the scale of the accident. ${ }^{38}$

Yet even if victims in Western Europe or Scandinavia were to suffer nuclear damage, they would not be entitled to claim compensation from the former USSR or from the Soviet operator, since rather than being contracting parties to the Vienna Convention, these states were actually parties to another convention, the 1960 Paris Convention on Third Party Liability in the Field of Nuclear Energy. ${ }^{39}$ There was therefore no link between the Vienna Convention and the Paris Convention. The contracting parties to the Vienna Convention were states that were not parties to the Paris Convention and vice versa, and the conventions did not apply to damage suffered on the territory of a state that was a contracting party to the other convention.

To resolve this issue, subsequent to the Chernobyl catastrophe, in 1988 the contracting parties to the two nuclear liability conventions adopted the Joint Protocol, ${ }^{40}$ which established a "bridge" between the two conventions for compensation for cross-border damage. ${ }^{41}$ Since the entry into force of the Joint Protocol in 1992, victims from states that are parties to the Paris Convention or the Vienna Convention have been entitled to compensation for such damage from the operator of a nuclear facility in the territory where the other convention applies.

The consequences of Chernobyl have illustrated the inadequacies of the nuclear liability conventions. Negotiations to revise the Vienna Convention began in 1989, and the contracting parties to the Paris Convention followed suit several years later. ${ }^{42}$ The results of these efforts

\footnotetext{
37 Vienna Convention on Civil Liability for Nuclear Damage (1963), IAEA Doc. INFCIRC/500, 1063 UNTS 266, entered into force 12 November 1977 (Vienna Convention).

${ }^{38}$ According to the Vienna Convention, the amount of the operator's liability is limited, since Article V provides that "The State in which the facility is located may restrict the liability of the operator to an amount which shall not be less than USD 5 million per nuclear accident."

${ }^{39}$ Convention on Third Party Liability in the Field of Nuclear Energy of $29^{\text {th }}$ July 1960 , as amended by the Additional Protocol of $28^{\text {th }}$ January 1964 and by the Protocol of $16^{\text {th }}$ November 1982 (1960), 1519 UNTS 329 (Paris Convention or PC). It must be added that the Brussels Supplementary Convention was adopted in 1963 to complete the compensation payable under the terms of the Paris Convention by establishing three cumulative bands of compensation. Convention of $31^{\text {st }}$ January 1963 Supplementary to the Paris Convention of $29^{\text {th }}$ July 1960 , as amended by the Additional Protocol of $28^{\text {th }}$ January 1964 and by the Protocol of $16^{\text {th }}$ November 1982 (1963), 1041 UNTS 358 (Brussels Supplementary Convention or BSC).

${ }^{40}$ Joint Protocol Relating to the Application of the Vienna Convention on Civil Liability for Nuclear Damage and the Paris Convention on Third Party Liability in the Field of Nuclear Damage (1988), IAEA Doc. INFCIRC/402, 1672 UNTS 293, entered into force 27 April 1992 (Joint Protocol).

${ }^{41}$ See von Busekist, O. (2006), “A bridge Between Two Conventions on Civil Liability for Nuclear Damage: The Joint Protocol Relating to the Application of the Vienna Convention and the Paris Convention", in NEA and IAEA (eds.), International Nuclear Law in the PostChernobyl Period, OECD, Paris, pp. 129-153.

${ }^{42}$ On the negotiations and their results, see NEA (2000), Reform of Civil Nuclear Liability: International Symposium, Budapest, Hungary, 31 May - 3 June 1999, OECD, Paris.
} 
were the Protocol to Amend the Vienna Convention ${ }^{43}$ on the one hand, ${ }^{44}$ and the Protocol to Amend the Paris Convention ${ }^{45}$ and the Protocol to Amend the Brussels Supplementary Convention $^{46}$ on the other (the latter two protocols have yet to enter into force). ${ }^{47}$ These amendments broadened the geographic scope of the conventions and expanded the notion of nuclear damage so that its definition included certain forms of damage to the environment, the costs of preventive measures and "economic loss". They also set out more stringent criteria for exonerating the operator and increased the amount of damages ${ }^{48}$ and the limitation period for claims, which was raised to 30 years in the case of loss of life or personal injury.

In the negotiations on the revision of the Vienna Convention, in parallel to its amendment, a new treaty was adopted: the Convention on Supplementary Compensation for Nuclear Damage. ${ }^{49}$ This instrument seeks to establish a worldwide liability regime and to make public funds available that establish an amount to supplement those made available by the existing systems as compensation for nuclear damage. ${ }^{50}$

The third nuclear catastrophe occurred on 11 March 2011 at the Fukushima Daiichi nuclear power plant in Japan. This was caused by a huge tsunami following an earthquake measuring 8.9 on the Richter scale, the epicentre of which was located in the Pacific Ocean $145 \mathrm{~km}$ from Fukushima. This accident was also classified at level 7 on the INES scale. Over 100000 people were subsequently evacuated because of radionuclide discharges into the environment, though the tragedy did not cause significant damage on the territory of foreign states.

Measures were taken worldwide after Fukushima to assess the safety of nuclear facilities in light of the lessons learnt from the accident, which "brought nuclear safety to the forefront of global

\footnotetext{
${ }^{43}$ Protocol to Amend the 1963 Vienna Convention on Civil Liability for Nuclear Damage (1997), IAEA Doc. INFCIRC/566, 2241 UNTS 302, entered into force 4 October 2003 (1997 Protocol to Amend the Vienna Convention).

${ }^{44}$ See Lamm, V. (2006), "The Protocol Amending the 1963 Vienna Convention” in NEA and IAEA (eds.), International Nuclear Law in the Post-Chernobyl Period, OECD, Paris, pp. 169-185.

45 Protocol to Amend the Convention on Third Party Liability in the Field of Nuclear Energy of 29 July 1960, as amended by the Additional Protocol of 28 January 1964 and by the Protocol of 16 November 1982 (2004) (not yet in force), available at: www.oecdnea.org/law/paris_convention.pdf (2004 Paris Protocol).

${ }^{46}$ Protocol to Amend the Convention of 31 January 1963 Supplementary to the Paris Convention of 29 July 1960 on Third Party Liability in the Field of Nuclear Energy, as amended by the Additional Protocol of 28 January 1964 and by the Protocol of 16 November 1982 (2004) (not yet in force), available at: www.oecd-nea.org/law/brussels_supplementary_convention.pdf (2004 Brussels Protocol).

${ }^{47}$ See Dussart Desart, R. (2005), "The Reform of the Paris Convention on Third-Party Liability in the Field of Nuclear Energy and of the Brussels Supplementary Convention”, Nuclear Law Bulletin, No. 75, OECD, Paris, pp. 7-33.

${ }^{48}$ The most notable amendments to the Conventions include the increase in the amounts of compensation. The Protocol to Amend the Vienna Convention provides that the legislation of the Installation State may limit the liability of the operator for any nuclear accident to not less than 300 million SDRs [Special Drawing Rights]; naturally, the upper limit of the operator's liability may be higher.

Under the Paris Convention, the operator's liability was limited to 15 million SDRs. The 2004 Protocol raised this band to a minimum of EUR 700 million. The second band was to be raised to between EUR 700 million and EUR 1.2 billion, payable by the Installation State (according to the Brussels Supplementary Convention, this band covered the difference between the first band and 175 million SDRs); finally, an international fund would henceforth contribute between EUR 1.2 and EUR 1.5 billion (the international fund provided for under the Brussels Supplementary Convention called for over 175 million SDRs up to 300 million SDRs).

Thus, under the 2004 Protocols, while maintaining the three-band system of compensation under the Brussels Supplementary Convention, the total compensation per accident available under the terms of the amended Paris-Brussels system amounted to EUR 1.5 billion.

${ }^{49}$ Convention on Supplementary Compensation for Nuclear Damage (1997), IAEA Doc. INFCIRC/567, 36 ILM 1473, entered into force 15 April 2015 (CSC).

${ }^{50}$ See McRae, B. (20011), "Convention on Supplementary Compensation for Nuclear Damage (CSC) and harmonisation of nuclear liability law within the European Union”, Nuclear Law Bulletin, No. 87, OECD, Paris, pp. 73-86.
} 
attention". 51 The nuclear countries and international organisations commissioned supplementary safety studies on nuclear installations, ${ }^{52}$ and on 25 March 2011, the EC took a decision to verify the safety of 143 European nuclear power plants and carry out global assessments of the respective risks and of the security of such plants ("stress tests"). ${ }^{53}$ In addition, a 2014 Directive on nuclear safety stressed the independence of the competent regulatory authority in its regulatory decision-making, stating that it was a fundamental requirement of the Community nuclear safety regulatory framework, and underscored the importance of enhancing transparency on nuclear safety matters. ${ }^{54}$

In legal terms, the events at the Fukushima Daiichi nuclear power plant demonstrated not only the importance of the CNS and the mechanism established by that international instrument, but also led the EU to study opportunities for improving and strengthening nuclear liability schemes. ${ }^{55}$ This was because the events in Japan also raised the question of whether nuclear power plant operators and the authorities of states with nuclear power plants were sufficiently prepared to respond to a serious nuclear accident. Subsequent to the Fukushima Daiichi accident, the Japanese Government introduced a range of measures to adapt the nuclear damage compensation scheme to the situation that had arisen, and the Japanese authorities established a special scheme for compensating victims of the accident. ${ }^{56}$

\section{Interaction between soft law norms and binding norms in the area of nuclear law}

Soft law norms or "advisory regulations" play a very important role in the area of the peaceful uses of nuclear energy, ${ }^{57}$ as the legal scheme governing peaceful uses of nuclear energy are grounded in a mix of binding norms and advisory regulations. ${ }^{58}$ The advisory regulations appear in the form of codes of conduct, recommendations or guidelines, etc. drawn up by expert groups of international nuclear organisations, particularly the IAEA, Euratom and the NEA, and subsequently approved by the governing bodies of those organisations. ${ }^{59}$ These norms provide the

\footnotetext{
${ }^{51}$ Johnson, P.L. (2013), “The post-Fukushima Daiichi response: The role of the Convention on Nuclear Safety in strengthening the legal framework for nuclear safety” Nuclear Law Bulletin, No. 91, OECD, Paris, p. 7.

${ }^{52}$ See NEA (2013), The Fukushima Daiichi Nuclear Power Plant Accident: OECD/NEA Nuclear Safety Response and Lessons Learnt, OECD, Paris.

${ }^{53}$ On lessons learned from the stress test, see ENSREG (2012), "Compilation of recommendations and suggestions: Peer review of stress tests performed on European nuclear power plants”, Doc. HLG_p(2012-20)_101.

${ }^{54}$ Council Directive 2014/87/Euratom of 8 July 2014 amending Directive 2009/71/Euratom establishing a Community framework for the nuclear safety of nuclear installations, OJ L 219 (25 July 2014) (2014 Amended Safety Directive).

${ }^{55}$ See Beyens, M. (2014), “The EU tentative to harmonise nuclear liability among the EU member states”, in Mariano Manovil, R. (ed.) (2014), Nuclear Law in Progress: XXI AIDN / INLA Congress - Buenos Aires 2014, Legis, Buenos Aires, pp. 663-670.

${ }^{56}$ See Legal Affairs Section of the OECD Nuclear Energy Agency (2011), "Regulatory and institutional framework in Japan against the background of Fukushima", Nuclear Law Bulletin, No. 87, OECD, Paris, pp. 27-44; Vásquez-Maignan, X. (2012), "Fukushima: liability and compensation", Nuclear Law Bulletin, No. 88, OECD, Paris, pp. 61-64; Nomura, T. (2014), "La droit japonais de la responsabilité des dommages nucléaires et son évolution après l'accident de Fukushima" [Japanese law of liability for nuclear damage and its evolution after the Fukushima accident], Revue juridique de l'environnement [Environmental Law Review], Vol. 39, No. 4, pp. 629-639.

${ }^{57}$ On the importance and advantages of advisory standards and regulations in nuclear matters, see Wetherall, A. (2005), "Normative Rule Making at the IAEA: Codes of Conduct", Nuclear Law Bulletin, No. 75, OECD, Paris, pp. 71-93.

${ }^{58}$ ElBaradei, M., E. Nwogugu and J. Rames (1995), "International law and nuclear energy: Overview of the legal framework", IAEA Bulletin, Vol. 37, No. 3, IAEA, Vienna, p. 16.

${ }^{59}$ For the codes of conduct adopted by the IAEA, see also Reyners, P. (2010), "Three International Atomic Energy Agency Codes", in NEA (ed.) (2010), International Nuclear Law: History, Evolution and Outlook, OECD, Paris, pp. 171-185; Boustany, K. (2001), “The IAEA Code of Conduct on the Safety of Radiation Sources and the Security of Radioactive Materials: A Step Forwards or Backwards?", Nuclear Law Bulletin, No. 67, OECD, Paris, pp. 9-20.
} 
international source for implementing national regulations by ensuring a level of uniformity, professionalism and accuracy.

Nowadays, these international organisations are producing an increasing number of technical guidelines and recommendations, and as the International Court of Justice (ICJ) ruled, in interpreting an agreement between the parties in the Pulp mills on the River Uruguay case (the "1975 Statute" ${ }^{\text {"60 }}$, the guidelines and recommendations of international technical bodies, while "not being formally binding, are, to the extent they are relevant, to be taken into account by the State so that the domestic rules and regulations and the measures it adopts are compatible ("con adecuación') with those guidelines and recommendations". 61 Thus according to the ICJ, despite their lack of binding force, these rules are of great practical importance.

The importance of soft law norms in nuclear law is reinforced by the fact that IAEA Safety Standards (the Safety Fundamentals, Safety Requirements and Safety Giudes) represent a minimum internationally acceptable standards of safety. Failure to adhere to these norms is regarded as a failure to fulfil the customary obligation of due diligence. ${ }^{62}$ In international nuclear law, several soft law norms have been converted over the years into treaty-based sources of international law, a trend that not only continued but intensified after the Chernobyl accident. ${ }^{63}$ The first stage of this process was the adoption of the Conventions referred to above on Early Notification and Assistance, both of which were founded on existing non-legally binding guidelines. $^{64}$

The Convention on the Physical Protection of Nuclear Material ${ }^{65}$ is a primary example of interaction between advisory regulations and treaty-based norms. The physical protection of nuclear material focuses mainly on physical protection against the theft or illegal use of nuclear material that could be used to produce a nuclear explosive device. ${ }^{66}$ This physical protection was therefore a matter of constant concern to the international community. In order to avoid such occurrences, soft law norms drafted by the IAEA had existed since the 1970s, particularly on the physical protection of nuclear material during transport, when such material is particularly vulnerable to the risk of diversion and use for illegal purposes. The CPPNM was adopted in 1980 on the basis of non-binding norms and provided for the physical protection of nuclear material during international transport, the penalisation of offences and international co-operation.

\footnotetext{
60 "The 1975 Statute" was the "regime for the use of the river" set out in Article 7 of the Treaty of Montevideo entered into between Argentina and Uruguay in 1961 concerning the border on the River Uruguay.

${ }^{61}$ Case Concerning Pulp Mills on the River Uruguay (Argentine v. Uruguay), Judgment of 20 April 2010, ICJ Reports, 2010 , p. 45.

${ }^{62}$ Boyle, A. (2014), "Soft Law in International Law-Making”, Evans, M.D. (ed.) (2014), International Law, Oxford University Press, Oxford, 4th Edition, pp. 127-128.

${ }^{63}$ Pelzer, N. (2006), supra note 25, pp. 83-84.

${ }^{64}$ See IAEA (1984), "Guidelines for Mutual Emergency Assistance Arrangements in Connection with a Nuclear Accident or Radiological Emergency", IAEA Doc. INFCIRC/310, IAEA, Vienna; IAEA (1985), "Guidelines on Reportable Events, Integrated Planning and Information Exchange in a Transboundary Release of Radioactive Materials”, IAEA Doc. INFCIRC/321, IAEA, Vienna.

${ }^{65}$ Convention on the Physical Protection of Nuclear Material, (1980), IAEA Doc. INFCIRC/274 Rev. 1, 1456 UNTS 125, entered into force 8 February 1987 (CPPNM).

${ }^{66}$ See Saizon Jr., D.L. (1980), “The Convention on the Physical Protection of Nuclear Material”, IAEA Bulletin, Vol. 22, No.3, IAEA, Vienna, pp. 57-62.
} 
In 2005, the CPPNM was amended by the contracting parties. ${ }^{67}$ They significantly extended the scope of the Convention, since the instrument concerned the physical protection not only of nuclear material but also of nuclear facilities for peaceful purposes against theft or any other unlawful taking of such material, acts of sabotage or terrorism. The title of the instrument accordingly changed to the Convention on the Physical Protection of Nuclear Material and Nuclear Facilities (CPPNMNF). ${ }^{68}$ The CPPNMNF also includes references to the soft law norms, since a new Article 2A provides for a number of "Fundamental Principles" of physical protection of nuclear material and facilities. The codification of advisory regulations in the CPPNM does not mean, however, that the soft law norms become less important. Rather, it is the combination of the CPPNM and its Amendment, along with the IAEA Nuclear Security Recommendations on the protection of nuclear material and nuclear facilities ${ }^{69}$ that comprise the international physical protection regime. $^{70}$

Both the CNS and the Joint Convention have a soft law basis. One of the characteristics of these two instruments is that they are classified in their preambles as "incentive conventions". The preamble to the CNS states that the instrument "entails a commitment to the application of fundamental safety principles for nuclear installations rather than of detailed safety standards and that there are internationally formulated safety guidelines which are updated from time to time and so can provide guidance on contemporary means of achieving a high level of safety" ${ }^{71}$ The second part of the above text clearly alludes to the soft law codes and guidelines drafted by the international nuclear organisations. The Joint Convention is more specific in this respect than the CNS, given that its preamble lists certain soft law standards: "[k]eeping in mind the principles contained in the interagency 'International Basic Safety Standards for Protection against Ionizing Radiation and for the Safety of Radiation Sources' (1996), in the IAEA Safety Fundamentals entitled 'The Principles of Radioactive Waste Management' (1995), and in the existing international standards relating to the safety of the transport of radioactive materials". 72

The incentive nature of the nuclear safety conventions has drawn criticism that they may create expectations rather than specific obligations. ${ }^{73}$ According to Menno Kaminga, the greatest weakness of the CNS is that it provides for courses of action rather than obligations to expect specific results. ${ }^{74}$ Another commentator, Norbert Pelzer, on the other hand stresses the incentive

\footnotetext{
${ }^{67}$ Amendment to the Convention on the Physical Protection of Nuclear Material (2005), IAEA Doc. INFCIRC/274/Rev.1/Mod.1, entered into force 8 May 2016 (ACPPNM). On the revision of the CPPNM, see Vez Carmona, M.d.L. (2005), "The International Regime on the Physical Protection of Nuclear Material and the Amendment to the Convention on the Physical Protection of Nuclear Material", Nuclear Law Bulletin, No.76, OECD, NEA, pp. 29-46; Johnson, P.L. (2014), "Facilitating the entry into force and implementation of the Amendment to the Convention on the Physical Protection of Nuclear Material: Observations, challenges and benefits", Nuclear Law Bulletin, No. 94, OECD, Paris, pp. 9-42.

${ }^{68}$ On the CPPNMNF, see Johnson, P.L. (2014), supra note 64.

${ }^{69}$ IAEA (2011), Nuclear Security Recommendations on Physical Protection of Nuclear Material and Nuclear Facilities, IAEA Doc. INFCIRC/225/Revision 5, IAEA, Vienna.

${ }^{70}$ Johnson, P.L. (2014), supra note 64, pp. 14-15.

${ }^{71} \mathrm{CNS}$, Preamble (viii).

${ }^{72}$ Joint Convention, Preamble (xiv).

${ }^{73}$ See Handl, G. (2004), "The IAEA Nuclear Safety Conventions: An Example of Successful 'Treaty Management'”? Nuclear Law Bulletin, OECD, Paris, No. 72, pp. 12-13.

${ }^{74}$ Kamminga, M.T. (1995), “The IAEA Convention on Nuclear Safety”, International and Comparative Law Quarterly, Vol. 44, No. 4, pp. 872-882.
} 
nature of the nuclear safety conventions as one of their advantages, considering them to be more respectful of the sovereignty of states and consequently more acceptable. ${ }^{75}$

The reference to soft law norms in the conventions certainly does not change the legal status of those standards, but it has increased their importance, which also demonstrates how the two types of norms can interact in complex areas. ${ }^{76}$ It should be added that this trend is not entirely new, and according to Günther Handl it exemplifies an ongoing wider trend in the design of multilateral (environmental or equivalent) agreements "that has increasingly de-emphasised coercive application/enforcement measures for the sake of a facilitative, co-operative approach", 77

There is no doubt that reference in the international conventions to the application of non-binding standards drafted by the international nuclear organisations demonstrates a certain flexibility in the system, as well as an adaptation to the demands of different states and to the development of nuclear science and technology without the need for a lengthy process of amending the conventions. The question nevertheless arises of whether the time has come to introduce binding standards into the nuclear safety conventions, especially when the standards in question are not technical and in particular bearing in mind that, over the past 20 years, nuclear safety culture (to use the terminology of the nuclear safety conventions $)^{78}$ has expanded throughout the world.

In taking account of the lessons of the Fukushima accident, it should be noted that a Diplomatic Conference to revise the CNS was convened in 2015 with the specific aim of reinforcing the CNS. The conference agenda included a Swiss proposal to introduce a new subparagraph into Article 18 of the Convention to improve the safety of future nuclear power plants and of existing power plants as far as possible. Regrettably, however, the amendment to the Convention was rejected, and rather than drafting binding norms, a declaration entitled the "Vienna Declaration on Nuclear Safety: On principles for the implementation of the objective of the Convention on Nuclear Safety to prevent accidents and mitigate radiological consequences"79 was adopted by consensus, and this is yet again a non-binding instrument. ${ }^{80}$ It would thus seem that the possibility of adopting non-binding rather than binding standards does not always help to improve nuclear safety, as illustrated here.

\section{Conclusion}

Since the beginning, efforts to eliminate or regulate the military uses of nuclear energy went hand-in-hand with the promotion of the peaceful uses. This demonstrates the responsibility and awareness of the international community of states, namely, that the prohibition and elimination

\footnotetext{
${ }^{75}$ Pelzer, N. (2013), "Safer nuclear energy through a higher degree of internationalisation? International involvement versus national sovereignty”, Nuclear Law Bulletin, No. 91, OECD, Paris, p. 84.

${ }^{76}$ Boyle, A. (1999), "Some Reflections on the Relationship of Treaties and Soft Law", International and Comparative Law Quarterly, 1999, Vol. 48, Part 4, p. 906.

${ }^{77}$ Handl, G. (2004), supra note 70, p. 10.

${ }^{78}$ On the notion of "nuclear culture", see Carnino, A. (1993), "Achievements in assessing safety culture”, Nuclear Law Bulletin, No. 52, OECD, Paris, pp. 28-34.

${ }^{79}$ See IAEA (2015), "Vienna Declaration on Nuclear Safety: On principles for the implementation of the objective of the Convention on Nuclear Safety to prevent accidents and mitigate radiological consequences", IAEA Doc. INFCIRC/872.

${ }^{80}$ The Declaration is based substantially on the principles of the European Union directive on the safety of nuclear installations. See Council Directive 2009/71/Euratom of 25 June 2009 establishing a Community framework for the nuclear safety of nuclear installations, OJ L 172 (2 July 2009) (2009 Safety Directive); 2014 Amended Safety Directive.
} 
of military uses of nuclear energy should not hamper its peaceful application, and also, on the other side of the coin, while promoting the peaceful application of nuclear energy, the diversion of peaceful applications of nuclear energy to military uses should be prevented. This duality has been reflected in several international instruments and in the activities of international organisations as well, and can be considered a special attribute of international nuclear law.

The impact of nuclear accidents on the development of international nuclear instruments is another special feature of international nuclear law. The scale and effects of catastrophic nuclear accidents are past all belief and have highlighted not only the technical shortcomings but also the gaps and incoherence in the legal framework for the peaceful use of nuclear energy. The new instruments adopted following the Chernobyl accident, as well as the amendments to existing conventions, strengthened and broadened the framework for international co-operation in the nuclear field, improved the position of potential victims of nuclear accidents, and increased the safety, security and physical protection of nuclear materials and installations. Nevertheless, these issues should be the subject of further consideration and all efforts and initiatives aimed at clarifying and detailing the content of the above-mentioned norms, as well as efforts to monitor their compliance, should be promoted and supported.

The interaction between soft law norms and treaty law is the last special aspect of the development of nuclear law, and one can see two trends. On the one hand, several soft law norms have been converted into treaty norms; and on the other hand, soft law norms, especially international standards and regulations, are referenced in international conventions. No doubt, the approach of using non-binding norms has great advantages, in view of their flexibility and the quick adoption in the development of science and technology. But, the preffered approach would be to introduce binding standards into, for example, the nuclear safety conventions, especially when the standards in question are not technical. 